Original Article

\title{
Monitoring of Insecticides resistance against cotton Jassid (Amrasca biguttutla biguttutla) under laboratory conditions
}

\author{
Monitoramento da resistência de inseticidas contra o algodão Jassid (Amrasca \\ biguttutla biguttutla) em condições laboratoriais
}

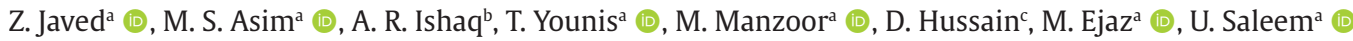 \\ and M. Asrar ${ }^{\text {** }}$ (D) \\ ${ }^{a}$ Government College University Faisalabad, Departments of Zoology, Faisalabad, Punjab, Pakistan

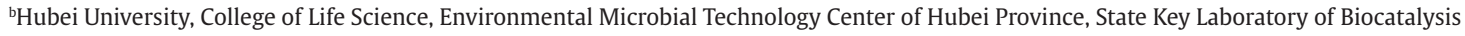 \\ and Enzyme Engineering, Wuhan, China \\ ‘Ayub Agricultural Research Institute, Entomological Research Institute, Faisalabad, Punjab, Pakistan
}

\begin{abstract}
Development of insecticides resistance mainly hinge with managements techniques for the control of Jassid, Amrasca biguttutla biguttutla. Five insecticides were applied against field collected and laboratory rared jassid populations during the years of 2017 to 2019 to profile their resistance level against field population of jassid through leaf dip method. Very low resistance level was found in jassid against confidor whereas high level of resistance was observed by pyriproxyfen against other test insecticides. Gradual resistance was observed against diafenthiuron. It is concluded that for the management of Jassid repetition of same insecticide should be avoided. The use of confidor may be reduced to overcome resistance against Jassid.
\end{abstract}

Keywords: Amrasca biguttutla biguttutla, confidor, insecticide's resistances, pyriproxyfen, IPM.

\begin{abstract}
Resumo
Desenvolvimento da resistência a inseticidas principalmente em dobradiça com técnicas de manejo para o controle de jassid, Amrasca biguttutla biguttutla. Cinco inseticidas foram aplicados contra populações de jassídeos coletados em campo e em laboratório durante os anos de 2017 a 2019 para traçar o perfil de seu nível de resistência contra populações de jassídeos em campo através do método de imersão nas folhas. Nível de resistência muito baixo foi encontrado em jassid contra confidor, enquanto alto nível de resistência foi observado por piriproxifeno contra outros inseticidas de teste. Resistência gradual foi observada contra o diafenthiuron. Conclui-se que, para o manejo do jassid, a repetição do mesmo inseticida deve ser evitada. $\mathrm{O}$ uso de confidor pode ser reduzido para superar a resistência contra jassid.
\end{abstract}

Palavras-chave: Amrasca biguttutla biguttutla, confidor, resistências a inseticidas, piriproxifeno, IPM.

\section{Introduction}

Cotton (Gossypium hirsutum L.) is the most yield crop of Pakistan subsequent rice and crop of wheat and it inhabits the key portion in Pakistan linked to further crops. Cotton yield produces state principal export incomes and in accumulation to the seed and lint of fiber used for the purpose of meal and fatty ingredient for $80.0 \%$ of national production oily seeds (ur Rahman et al., 2018). The overall products of cotton to subsidizes 10\% to GDP and 55\% to overseas earning for our homeland (Rehman et al., 2019).

The cotton crop of different areas is an efficiently vital fibrous crop of Pakistan (Rehman et al., 2016). Many factors like floods, heavy monsoon, infestation of sucking insect pests and cotton leaf curl virus (CLCV) disease have resulted a decline in $13.4 \%$ of cotton area during the years 2010-11 (Bakhsh et al., 2019; Egler et al., 2012; Guedes et al., 2020).

Cotton is one of the major fiber crop grown in more than 80 countries of temperate and tropical regions. Sucking pests have become quite serious from seedling stage. Chavan et al. (2010) reported 28.13 per cent avoidable yield loss due to major sucking pests in cotton. Among these whitefly and jassid is the deadliest pest and reduces the crop yield to a great extent (Alyokhin et al., 2020).

The chemical control is the one of the rapid methods and is an integral part and tool of integrated pest management (IPM) program to reduce the losses caused by sucking insect pests to the cotton crop (Aslam et al., 2004). Various researchers have conducted the research regarding the

*e-mail: asrar_agri@yahoo.com

Received: January 17, 2021 - Accepted: June 12, 2021

This is an Open Access article distributed under the terms of the Creative Commons Attribution License, which permits unrestricted use, distribution, and reproduction in any medium, provided the original work is properly cited. 
effectiveness of different insecticides against sucking insect pests of cotton crop (Ghosh, 2020).

In Pakistan, pesticides worth more than 10 billion rupees are imported, out of which about $70-80 \%$ are sprayed against cotton pests (Bashir et al., 2020). It is the foremost need to use the new insecticides which not only control the target insect pest (Galdino et al., 2021) but also protect the beneficial insects like ladybird beetle, spider, Chrsoperllaspp, Trichogrammaspp and human being (Botha et al., 2020; Egler et al., 2012). Pesticides cause foodborne illness in human through intoxication of various food items (Ishaq et al., 2021). Present study was conducted to compare the efficacy of new insecticides at different time intervals, against jassid, under the laboratory conditions on cotton.

Agriculture in Pakistan shows a vibrant part and pays to rise as a dealer the basic source of raw material to industry and which is a significant source of imported export income (Syed et al., 2020). Agriculture zone in Pakistan has presented a growth of yield 3.22, 3.34 percent livestock, 3.70, forestry 1.12 and fishery 0.749 percent. Amongst other all yields, the main yields (cotton, tobacco, maize, rice, wheat, and sugarcane) produce by 2.31 percent and extra product by 6.71 percent (oilseed, pulses, etc.) are involved (Ishfaq et al., 2020; Ahmad et al., 2020)

Keeping in consideration the above-mentioned facts, different insecticides were examined in this study to test their resistance level against adult cotton Jassid. This work provides new insights to monitor the harmful insect for crops and provide us most effective insecticides for commercial application.

\section{Materials and Methods}

The experiment was conducted at Toxicology Laboratory Entomological Research Institute, Ayub Agricultural Research Institute Faisalabad in the years of 2017-2019 to test the resistance of five different insecticides namely Soft Start (acetamiprid) 20SL, Confidor (imidacloprid) 200SL, Trophy (diafenthiuron) 500EC, Hy-Flow (pyriproxifen) 10.8EC and Pirate (chlorfenapyr) 360SC against cotton jassid under laboratory condition. The experiment was arranged in completely randomized design including control. Selected insecticides for experiment were obtained from commercial market and corrected mortality rate were calculated from field recommended doses using Formula 1 given below.

Corrected Mortality $=\frac{\text { No. of Insects in Control }- \text { No. of Insects Treated }}{\text { No. of Insects in Control }}$

The adults were collected randomly from the field of cotton plant leaves and put them in petri dishes under lab conditions as shown in Figure 1. Humidity was maintained by placing a humidifier. The adults were selected for treatment. Temperature $\left(24-26^{\circ} \mathrm{C}\right)$ and Relative Humidity
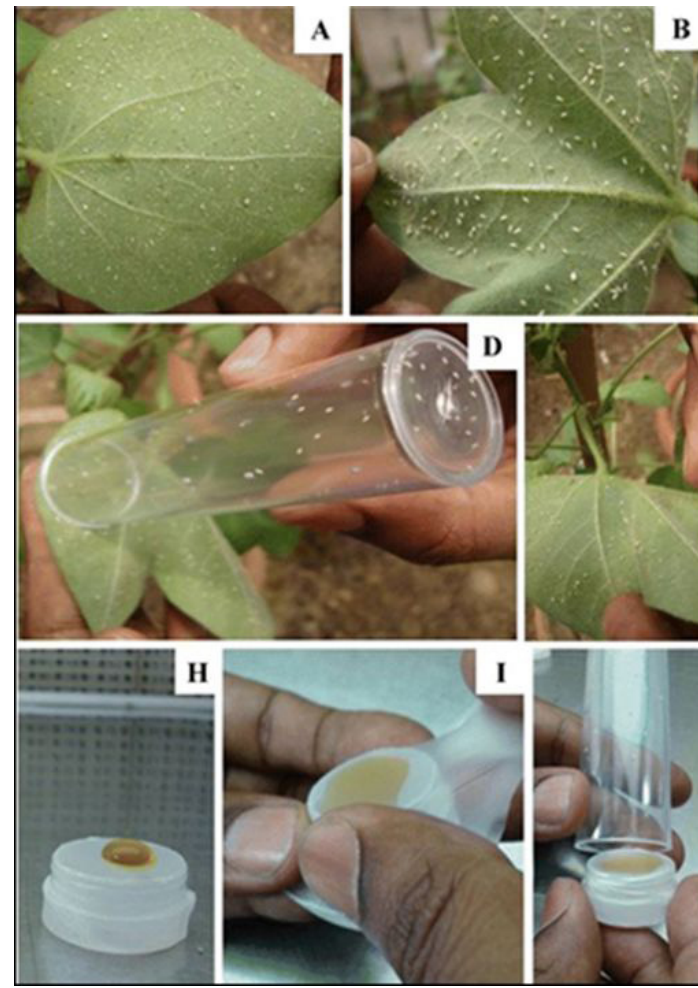
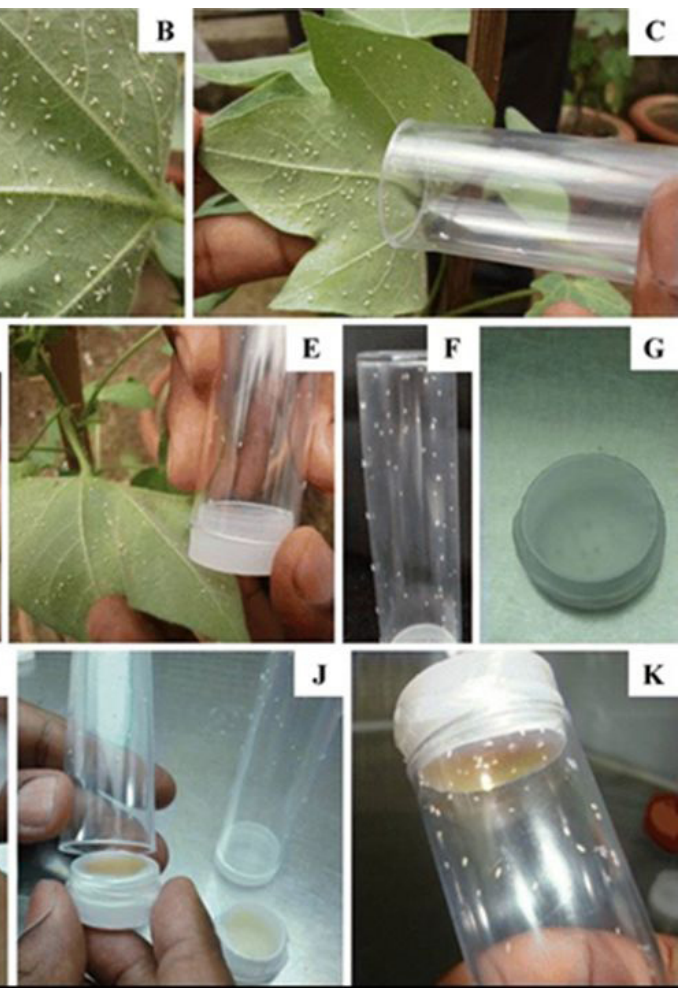

Figure 1. Precise stepwise method to collect the JASSID. 
$60 \pm 5 \%$. There were 6 treatments including control, having 5 repeats each. The insecticides were tested using leaf dip.

Serial dilutions of each dose of insecticide were made and leaves cut with leaf disc cutter according to the size of small plastic petri dishes $(5 \mathrm{~cm})$, were dipped in the insecticide solution. Treated leaves were then air dried at ambient room temperature as shown in Figure 2.5 adults of Jassid were released per treatment i.e 5 insects per leaf. The control leaves were dipped in water.

only. I took 30 petri-dishes for jassid and place five jassid in one petri-dish. Among these petri-dishes 5 were left untreated for control in such a way that 10 for adults and 15 were treated at $0.1 \%$ insecticides viz., SoftStart (acetamiprid) 20SL, Confidor (imidacloprid) 200SL, Trophy (diafenthiuron) 500EC, Hy-Flow (pyriproxifen) 10.8EC and Pirate (chlorfenapyr) 360SC. Similarly, I made 2nd standard concentration $0.2 \%$ and treat the leaves and release insects on moisturized leaves. Data was taken after different time intervals i-e 24 hours, 48 hours, 72 hours interval. The effectiveness of all insecticide's concentrations was estimated by counting the number of dead and alive insects after each interval.

\section{Data Analysis}

Lc50 calculated by using prohibit analysis and resistance factor was also worked out. The data was analyzed by means of analysis of variance techniques. The treatments means were compared by test at $5 \%$ significance level. The population means of sucking insect Jassid (Amrasca biguttutla biguttutla) calculated and significance level observed with LSD at 5\% internal using Probit analysis.

\section{Results}

Table 1 shown that confidor, a water-soluble granules which has highest mortality rate $\geq 72 \%$ towards Jassid at recommended $0.2 \%$. Just like that $0.1 \%$ low confidor also

Table 1. Percentage mortality of jassid after different time intervals.

\begin{tabular}{|c|c|c|c|c|}
\hline \multirow{2}{*}{ CONCENTRATION } & \multirow{2}{*}{ INSECTICIDES } & \multicolumn{3}{|c|}{ TIME INTERVAL } \\
\hline & & 24 HRS & 48 HRS & 72 HRS \\
\hline \multirow{6}{*}{ RECOMMENDED 0.2\% } & SoftStart (Acetamiprid) & $26 \%$ & $42 \%$ & $68 \%$ \\
\hline & Confidor (imidacloprid) & $48 \%$ & $63 \%$ & $72 \%$ \\
\hline & Trophy (diafenthiuron) & $47 \%$ & $62 \%$ & $66 \%$ \\
\hline & Hy-Flow (pyriproxifen) & $49 \%$ & $54 \%$ & $65 \%$ \\
\hline & Pirate (chlorfenapyr) & $44 \%$ & $63 \%$ & $71 \%$ \\
\hline & Control & $10 \%$ & $25 \%$ & $40 \%$ \\
\hline \multirow{5}{*}{ LOW $0.1 \%$} & SoftStart (Acetamiprid) & $12 \%$ & $25 \%$ & $42 \%$ \\
\hline & Confidor (imidacloprid) & $27 \%$ & $39 \%$ & $47 \%$ \\
\hline & Trophy (diafenthiuron) & $24 \%$ & $34 \%$ & $42 \%$ \\
\hline & Hy-Flow (pyriproxifen) & $30 \%$ & $35 \%$ & $39 \%$ \\
\hline & Pirate (chlorfenapyr) & $26 \%$ & $36 \%$ & $43 \%$ \\
\hline
\end{tabular}

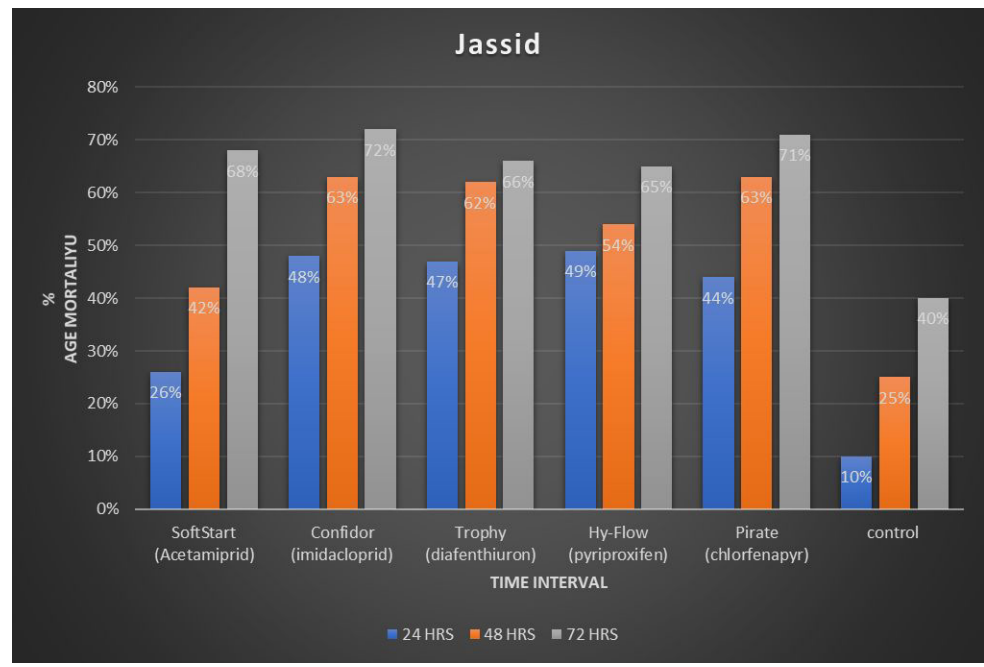

Figure 2. Recommended value $0.2 \%$ for mortality rate of JASSID. 


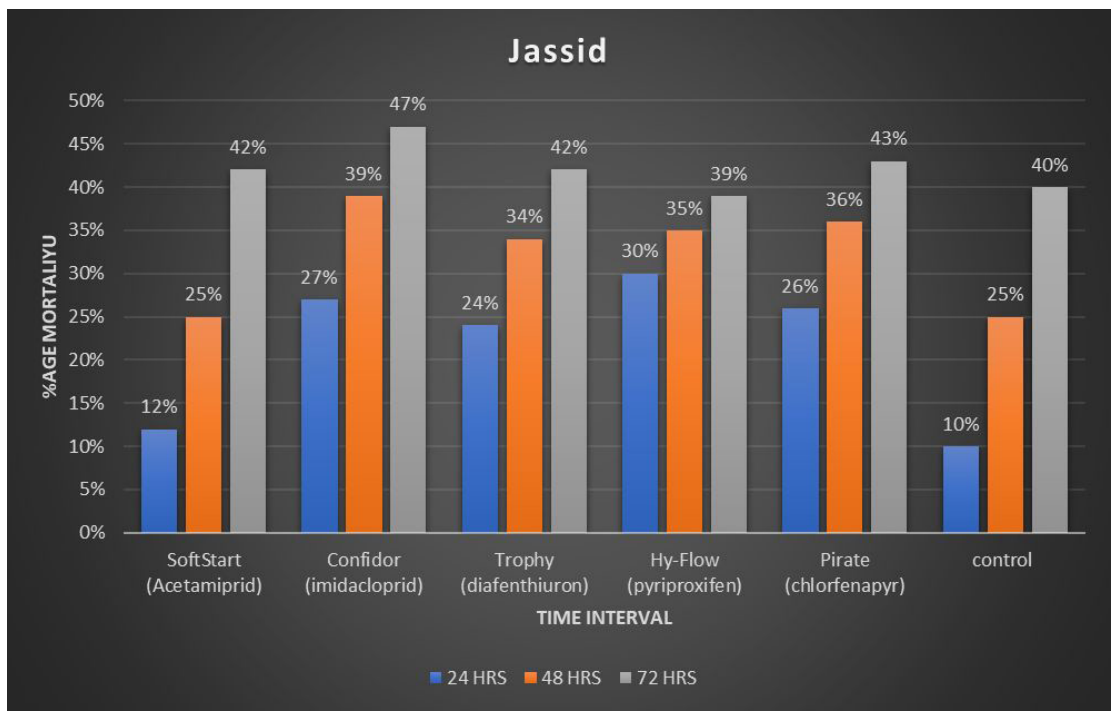

Figure 3. Low value $0.1 \%$ for mortality of JASSID.

shown highest mortality rate $\geq 47 \%$. This means jassid show least resistance against confidor and effective insecticide for commercial application. Pyriproxifen (a natural growth stunt hormone in insects) shown least mortality rate at recommended value as well as $0.1 \%$ low value.

Below Figure 3 shown that when different chemical insecticides were used to observe the mortality of jassid in different time of interval 72 hours, 48 hours, and 24 hours respectively.

\section{Acetamiprid}

Acetamiprid @ 0.2\% was applied 68\% mortality of jassid was observed after 72 hours followed by 48 hours and 24 hours which was $70 \%$ and $20 \%$ respectively. While in control treatment maximum mortality was after 72 hours which was $72 \%$.

\section{Imidacloprid}

Imidacloprid @ 0.2 was applied 72\% mortality of jassid was observed after 72 hours followed by 48 hours and 24 hours which was 70\% and 20\% respectively.

\section{Diafenthiuron}

Diafenthiuron @ 0.2 was applied 66\% mortality of jassid was observed after 72 hours followed by 48 hours and 24 hours which was $62 \%$ and $47 \%$ respectively.

\section{Pyriproxifen}

Pyriproxifen @ 0.2 was applied 65\% mortality of jassid was observed after 72 hours followed by 48 hours and 24 hours which was $54 \%$ and $49 \%$.

\section{Chlorpfempyr}

Chlorfenapyr @ 0.2 was applied 66\% mortality of jassid was observed after 72 hours followed by 48 hours and 24 hours which was $62 \%$ and $47 \%$ respectively.

Above Figure 4 shows that when different chemical insecticides were used to observe the mortality of jassid by different time of interval 72 hours, 48 hours and 24 hours respectively.

\section{Acetamiprid}

Acetamiprid @ 0.1\% was applied 42\% mortality of jassid was observed after 72 hours followed by 48 hours and

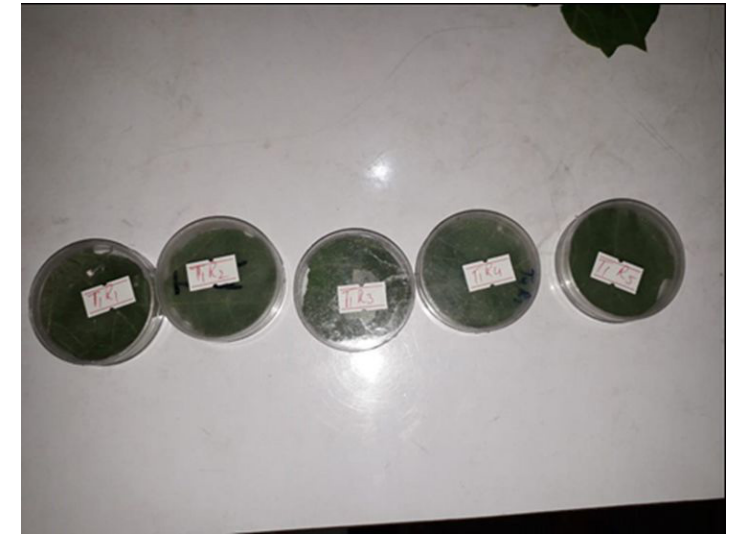

Figure 4. Tagged Petri dishes for results.

24 hours which was $25 \%$ and $12 \%$ respectively. While in control treatment maximum mortality was after 72 hours which was $72 \%$.

2. Imidacloprid

Imidacloprid @ 0.1 was applied 47\% mortality of jassid was observed after 72 hours followed by 48 hours and 24 hours which was $39 \%$ and $27 \%$ respectively.

3. Diafenthiuron

Diafenthiuron@ 0.1 was applied 42\% mortality of jassid was observed after 72 hours followed by 48 hours and 24 hours which was $34 \%$ and $24 \%$ respectively.

4. Pyriproxifen

Pyriproxifen @ 0.2 was applied 30\% mortality of jassid was observed after 72 hours followed by 48 hours and 24 hours which was 35\% and 30\%.

5. Chlorpfempyr

Chlorfenapyr @ 0.2 was applied 43\% mortality of jassid was observed after 72 hours followed by 48 hours and 24 hours which was $36 \%$ and $26 \%$ respectively. 


\section{Discussion}

A laboratory study was conducted to check the efficacy of different concentration of insecticide (SoftStart (acetamiprid) 20SL, Confidor (imidacloprid) 200SL, Trophy (diafenthiuron) 500EC, Hy-Flow (pyriproxifen) 10.8EC and Pirate (chlorfenapyr) 360SC) against jassid (Amrasaca biguttula biguttula) in cotton crop. Jassid is most considered as most damaging pest of cotton crop. Experiment was conducted to find out the best concentration of the new chemistry insecticides for the proper control of jassid (Amrasaca biguttula biguttula). My study results were revealed that higher concentration of insecticide other than recommended dose was more effective against jassid (Amrasacabiguttulabiguttula). On lower concentration, there was less mortality of jassid (Amrasaca biguttula biguttula) observed. Considerable control of jassid (Amrasaca biguttula biguttula) was observed on recommended dose of the confidor at 72 hour with $72 \%$ mortality rate.

Our findings were supported by (Hameed et al., 1997; Asi et al., 2008) who have investigated confidor has highly effective against jassid. (Yazdani et al., 2000) also proved our results that confidor has better mortality rate of jassid. (Khattak et al., 2004) also proved 200SL of confidor was significantly more effective against jassid than at 24 hours and 72 hours after spray. All previous research proved that confidor is beneficial insecticide to control the insect within mean time.

\section{Conclusion}

It has been examined that jassid management techniques play vital role in the progression of resistance to insecticides. Jassid population was most susceptible for confidor while it found to be resistant to other insecticides. Therefore, Insect pest Management (IPM), strategies should be included confidor is an alternative to other insecticides with poor mortality rate for sake of enhancing the cotton production.

\section{Reference}

AHMAD, K.J., HUSSAIN, D., KANWAL HANIF, Q.A., MUNIR, M., HAFEEZ, F., ZUBAIR, M., ASLAM, A., SALEEM, M.J., AKRAM, M. and MALIK, M.K., 2020. Monitoring of insecticide resistance against cotton whitefly (Bemesia Tabaci) under laboratory conditions. Life Science Journal, vol. 17, no. 8, pp. 1-5.

ALYOKHIN, A., NAULT, B. and BROWN, B., 2020. Soil conservation practices for insect pest management in highly disturbed agroecosystems: a review. Entomologia Experimentalis et Applicata, vol. 168, no. 1, pp. 7-27. http://dx.doi.org/10.1111/ eea.12863.

ASI, M.R., AFZAL, M., ANWAR, S.A. and BASHIR, M.H., 2008. Comparative efficacy of insecticides against sucking insect pests of cotton. Pakistan Journal of Life and Social Sciences, vol. 6, pp. 140-142.

ASLAM, M., RAZAQ M., SHAH, S.A. and AHMAD, F., 2004. Comparative efficacy of different insecticides against sucking pests of cotton. Journal of Research (Science), vol. 15, no. 1, pp. 53-58.

BAKHSH, A., REHMAN, M., SALMAN, S. and ULLAH, R., 2019. Evaluation of cotton genotypes for seed cotton yield and fiber quality traits under water stress and non-stress conditions.
Sarhad Journal of Agriculture, vol. 35, no. 1, pp. 161-170. http:// dx.doi.org/10.17582/journal.sja/2019/35.1.161.170.

BASHIR, M.A., ATTA, S., NISAR, M.S., KHAN, A.K., BATOOL, M., KHAN, K.A., GHRAMH, H.A. and AL-KAHTANI, S., 2020. Management of sucking insects pest complex of cotton through foliar spray of insecticides. Fresenius Environmental Bulletin, vol. 29, no. 7A, pp. 5777-5785.

BOTHA, A.M., KUNERT, K.J., MALING'A, J. and FOYER, C.H., 2020. Defining biotechnological solutions for insect control in sub Saharan Africa. Food and Energy Security, vol. 9, no. 1, pp. e191. http://dx.doi.org/10.1002/fes3.191.

CHAVAN, S., BHOSLE, B. and BHUTE, N., 2010. Estimation of losses due to major insect-pests in desi cotton (Gossypium arboreum L.) in Maharashtra. Journal of Cotton Research and Development, vol. 24, pp. 95-96.

EGLER, M., BUSS, D., MOREIRA, J. and BAPTISTA, D., 2012. Influence of agricultural land-use and pesticides on benthic macroinvertebrate assemblages in an agricultural river basin in southeast Brazil. Brazilian Journal of Biology $=$ Revista Brasileira de Biologia, vol. 72, no. 3, pp. 437-443. http://dx.doi.org/10.1590/ S1519-69842012000300004. PMid:22990812.

GALDINO, J., SILVA, C., ZANUNCIO, J. and CASTELLANI, M., 2021. Susceptibility of Alabama argillacea and Chrysodeixis includens (Lepidoptera: Noctuidae) larvae to Beauveria bassiana associated with kaolin. Brazilian Journal of Biology $=$ Revista Brasileira de Biologia, vol. 81, no. 4, pp. 1023-1029. http://dx.doi. org/10.1590/1519-6984.233340.

GHOSH, S.K., 2020. Evaluation of safe insecticides against sucking pests, jassid (Amrasca bigutula bigutula Ishida) and aphid (Aphis gossypii Glov.) infesting chilli (Capsicum annum L.) crop. Journal of Entomology and Zoology Studies, vol. 8, pp. 1428-1433.

GUEDES, V.S., SILVA, C.A.D. and ZANUNCIO, J.C., 2020. Survival, development and reproduction of Phenacoccus solenopsis (Hemiptera: Pseudococcidae) on kaolin-treated cotton. Brazilian Journal of Biology = Revista Brasileira de Biologia, vol. 80, no. 4, pp. 711-716. http://dx.doi.org/10.1590/1519-6984.216184.

HAMEED, M., MURTAZA, M. and BHATTI, M., 1997. Relative efficacy of new insecticides against insect pest complex of cotton. Pakistan Entomologist, vol. 19, pp. 70-72.

ISHAQ A.R., MANZOOR, M., HUSSAIN, A., ALTAF,J., REHMAN, S., JAVED, Z., AFZAL, I., NOOR, A. and NOOR, F., 2021. Prospect of microbial food borne diseases in Pakistan: a review. Brazilian Journal of Biology = Revista Brasileira de Biologia, vol. 81, no. 4, pp. 940-953. http://dx.doi.org/10.1590/1519-6984.232466. PMid:33605364.

ISHFAQ M., AKBAR, N., ANJUM, S.A. and ANWAR-IJL-HAQ, M., 2020. Growth, yield and water productivity of dry direct seeded rice and transplanted aromatic rice under different irrigation management regimes. Journal of Integrative Agriculture, vol. 19, no. 11, pp. 2656-2673. http://dx.doi.org/10.1016/S20953119(19)62876-5.

KHATTAK, M.K., ALI, S., CHISHTI, J.I., SALJIKI, A.R. and HUSSAIN, A.S., 2004. Efficacy of certain insecticides against some sucking insect pests of mungbean (Vigna radiata L.). Pakistan Entomologist, vol. 26, pp. 75-80.

REHMAN, A., JINGDONG, L., CHANDIO, A.A., HUSSAIN, I., WAGAN, S.A. and MEMON, Q.U.A., 2019. Economic perspectives of cotton crop in Pakistan: a time series analysis (1970-2015). Part 1. Journal of the Saudi Society of Agricultural Sciences, vol. 18, no. 1, pp. 49-54. http://dx.doi.org/10.1016/j.jssas.2016.12.005.

REHMAN, A., JINGDONG, L., DU, Y., KHATOON, R., WAGAN, S.A. and NISAR, S.K., 2016. Flood disaster in Pakistan and its impact on agriculture growth: a review. Environment and Development Economics, vol. 6, pp. 39-42. 
SYED, A., SARWAR, G., SHAH, S.H. and MUHAMMAD, S., 2020. Soil salinity research in $21^{\text {st }}$ century in pakistan: its impact on availability of plant nutrients, growth and yield of crops. Communications in Soil Science and Plant Analysis, vol. 253-254, pp. 1-18.

UR RAHMAN, M.H., AHMAD, A., WANG, X., WAJID, A., NASIM, W., HUSSAIN, M., AHMAD, B., AHMAD, I., ALI, Z. and ISHAQUE, W., 2018. Multi-model projections of future climate and climate change impacts uncertainty assessment for cotton production in Pakistan. Agricultural and Forest Meteorology, vol. 253, pp. 94-113. http://dx.doi.org/10.1016/j.agrformet.2018.02.008.

YAZDANI, M., SOHAIL, A., RAZAQ, M. and KHAN, H., 2000. Comparative efficacy of some insecticides against cotton Jassids (Amrasca devastans Dist.) and their on effect nontarget insects in cotton. International Journal of Agriculture and Biology, vol. 2, pp. 19-20. 